\title{
DATOS SOBRE EL TRABAJO DE LA MUJER EN ESPAÑA
}

\author{
Pilar Alcobendas Tirado \\ - (Centro de Investigaciones Sociológicas, «Colección Monografías», \\ núms. 68, 1983, 218 páginas, Madrid)
}

En el moment de la seva publicació, l'obra de P. Alcobendas va contribuir a posar al dia les dades bàsiques caracteritzadores del treball de la dona a l'Estat espanyol. Segons l'autora, es tracta d'una versió actualitzada de «L'emploi des femmes en Espagne», informe elaborat per a la «Direction Général de l'Emploi, des Affaires Socials et de l'Education» de la Comissió de les Comunitats Europees, del qual en manté l'estructura formal.

L'objectiu és esbrinar, per mitjà del tractament de dades secundàries, algunes de les causes afavoridores de la «desigualtat social» entre homes i dones, referint-se, especialment, al treball productiu, durant el periode 1970-1982. Alcobendas es forneix d'una àmplia informació, organitzada en onze capítols, que li permet descriure la «situació objectiva» de la dona en el procés educatiu i productiu, evidenciar els desajustos existents (en el temps considerat) entre legisłació i situació de fet de la dona i les actituds socials manifestades vers el treball de la dona fora de la llar.

Es considera que una legislació restrictiva, penalitzadora del treball extra-domèstic de les dones, juntament amb una forta presència de valors $i$ actituds perpetuadores del paper tradicional de la dona com a mare $i$ esposa, han dificultat l'accés de les espanyoles al treball productiu, mesurat per la seva participació en la població activa. D'ací que la representació femenina en l'educació $i$ en la producció es concentri en àmbits on la seva activitat és una perllongació de les tasques realitzades a la llar. Pel que fa a l'activitat productiva, aquesta tendència es modifica lleument 
en la primera meitat dels anys setanta; canvi expressat en un increment en el percentatge de dones considerades actives segons els indicadors convencionals, ocupades en sectors típicament femenins. La crisi entorpeix el flux d'entrada de dones al mercat de treball, frenant el creixement de l'activitat productiva femenina. L'escassa presència de la dona en tasques productives $i$, en general, la no consideració per part dels sindicats de l'especificitat del treball de la dona, mantenen allunyades les treballadores de les organitzacions que haurien de representar els seus interessos. Com a comentari final, només afegir que, sense qüestionar ni la validesa ni la necessitat de conèixer les dades «objectives» presentades per Alcobendas, cal precisar que si el que pretenem és explicar la situació de les dones en la producció, la descripció de les xifres esdevé un instrument d'anàlisi insuficient. Malgrat fer esment de l'especificitat del treball de la dona, aquest tipus de perpectiva manté la dicotomia producció/reproducció -esferes desigualment protagonitzades per ambdós sexes-, construint tot l'entrallat explicatiu del treball no domèstic de la dona segons un model d'activitat productiva masculí. I cal recordar que la revisió de conceptes i categories d'anàlisi i la no separació dels àmbits productiu $\mathrm{i}$ reproductiu són, a hores d'ara, qüestions prescindibles en l'anàlisi del treball productiu femení i masculí.

Pilar Carrasquer 